\title{
Playing with Philosophy: gestures, life-performance, P4C and an art of living.
}

An article published in ACCESS Special Issue of Educational Philosophy and Theory.

Please cite published article: DOI: 10.1080/00131857.2017.1294974 


\title{
Playing with Philosophy: gestures, life-performance, $\mathrm{P4C}$ and an art of living.
}

\author{
LAURA D'Olimpio \& CHRISTOPH TESCHERS \\ The University of Notre Dame Australia; New Zealand Tertiary College \\ Emails: laura.dolimpio@nd.edu.au ; christoph@teschers.com
}

\begin{abstract}
It can hardly be denied that play is an important tool for the development and socialisation of children. In this article we argue that through dramaturgical play in combination with pedagogical tools such as the Community of Inquiry (CoI), in the tradition of Philosophy for Children (P4C), students can creatively think, reflect and be more aware of the impact their gestures have on others. One of the most fundamental aspects of the embodied human life is human interaction that is based on expressions, what Schmid calls gestures. Through self-reflection, one's set of gestures can be developed into a deliberate 'life-performance' - a conscious, selected and coherent work of art. Drawing on Nietzsche's idea of living artistically, we explore how Schmid's philosophy of the art of living, P4C and the liberal arts, with a focus on drama education, can work together to help children develop their own art of living while respecting and supporting the development of the good and beautiful life of others.
\end{abstract}

Keywords: P4C, art of living, gestures, life-performance, CoI, drama education.

\section{Introduction}

One of the most fundamental aspects of the embodied human life is human interaction that is based on expressions, or what Schmid (2000b) calls gestures. Gestures, in Schmid's reading, are any form of expressions of one's inner self, one's core being. They include speech, any noise, facial expressions, hand gestures, body language, deliberate silence, and any other perceivable action or non-action. Every person - influenced by their individual development, their families, their peers and their general socialisation through parents, community and school - develops their own set of gestures to express themselves and to interact with others. Therefore, the nature and shape of gestures a person/child develops has a significant impact on his or her role in and interaction with society. However, not only deliberate expressions communicate with and to other human beings, but all gestures, conscious and unconscious, impact on whoever is witness to these gestures. Therefore, Schmid emphasises the significance of a conscious reflection on one's set of gestures and their impact on others. Through self- 
reflection, one's set of gestures can be developed into a deliberate life-performance, a conscious, selected and coherent work of art (Schmid, 2000b, p. 332). Schmid's concept of the art of living is inspired, among others, by Nietzsche's idea of living life as an artist. By considering how Philosophy for Children (P4C) practitioners may engage with concepts of art and drama, and linking this to Schmid's concept of gestures within his pedagogy for the art of living, we explore how philosophical play can help children develop their own art of living while respecting and supporting the development of the good and beautiful life of others.

We will start by explaining Nietzsche's concept of living one's life as an artist which involves making constructive use of our rational as well as our affective capacities as embodied human beings. In The Birth of Tragedy, Nietzsche (1872) refers to two energies: the rational Apollonian and the passionate Dionysian. We explore how both are useful in order to reflect on the meaning made via our interaction with the world. We will then use Schmid's (2000a) discussion of the art of living to further flesh out this aesthetic notion of the life lived as an artist. Finally, we discuss $\mathrm{P} 4 \mathrm{C}$ pedagogy in combination with drama education as a means by which we can encourage the practice of gestures that will form reflected habits and a purposeful life-performance for the development of students' own art of living.

\section{Nietzsche on Dionysus and Apollo and Living one's Life as an Artist}

In Friedrich Nietzsche's first major work, The Birth of Tragedy, published in 1872, the idea of living life creatively is embodied in his idea of living life as an artist. Nietzsche refers to two conflicting creative energies: the Apollonian and the Dionysian. The Apollonian is the cool rational intellect, while the Dionysian is the passionate emotional aspect. Here we follow Kerruish (2009) in arguing that the emotions are not irrational forces but, rather, may work alongside reason within Nietzsche's theoretical framework. Nietzsche worried that the society of his time only emphasised Apollonian energy and neglected the role of the Dionysian. Rationalists like Plato, Descartes, Spinoza and Kant emphasised humans as essentially rational, and believed irrational emotions ought to be kept under strict control (Kerruish, 2009, p. 17). Yet, Nietzsche thought it was important to balance our rationality with our sensual and passionate experience of life, and he saw this balance best depicted in ancient Greek tragedies.

Nietzsche insists that Greek tragedy achieves greatness through the inclusion of both Apollonian creative energy, responsible for the dialogue, and Dionysian energy, which inspires the music or chorus. In the plays, the two work together as the meaning of the words are enhanced by the accompanying melody. Using Greek dramatic artworks as an example, we can learn from great art to see the beauty in life. The tragic spectator is united with others in the shared experience of being human. For Nietzsche, life without emotion, art and the creative energy of the Dionysian is bleak. Both Dionysus and Apollo are required for authentic modes of expression that are rational as well as creative. The Birth of Tragedy opens thusly: '[w]e shall do a great deal for the 
science of esthetics, once we perceive not merely by logical inference, but with immediate certainty of intuition, that the continuous development of art is bound up with the Apollonian and Dionysian duality...' (1872, p. 1).

Nietzsche sees these two creative energies as 'natural' (p. 2) as he claims they 'burst forth from nature herself, without the mediation of the human artist...'. Yet, the crucial question is how we might use these 'art-impulses of nature,' and Nietzsche notes '[w]e now approach the real goal of our investigation, which is directed towards acquiring a knowledge of the Dionysian-Apollonian genius and its art-product' (p. 13); such genius recognises wisdom as expansive in that it includes experiential knowledge. Nietzsche suggests that a regeneration of art (the Dionysian) is desirable and that which is intelligible includes both logic (the Apollonian) and poetry...the wisdom of both the scientist and the artist. Art is suggested as a necessary supplement to logic and science; the aesthetic is another realm of knowing (p. 51).

There are many reasons the arts are valuable and Nietzsche gives the example of Ancient Greek tragedy as an art form that assists us to value life even when it is difficult or tragic. Considering the question of what it is that we learn from art, Nietzsche claims (p. 60) that 'Dionysian art...wishes to convince us of the eternal joy of existence' whereby we are not frightened by the temporal nature of things, rather we are uplifted by the 'Dionysian ecstasy, the indestructibility and eternity of this joy.' It is unusual to hear Nietzsche sound so optimistic as he writes, 'In spite of fear and pity, we are the happy living beings, not as individuals, but as the one living being, with whose creative joy we are united' (p. 60). These ideas are also reflected in his later writings, such as in The Will to Power, where Nietzsche calls for 'art as the redemption of the man of action ... Art as the redemption of the sufferer' (853: II). This sentiment that the arts and the study of the humanities is valuable alongside the knowledge gained from maths and sciences is still incredibly relevant today.

Nietzsche shows how art teaches a love for order and discipline while also allowing for the unknown or existential aspect of being human. Referring to Nietzsche's Birth of Tragedy, Nussbaum (1998a) notes '[ $\mathrm{t}]$ he arts show us that we can have order and discipline and meaning and logic from within ourselves: we do not have to choose between belief in god and empty chaos' (p. 59). Art can offer spectators the opportunity to view representations of life in various guises and empathetically celebrate the complexity of being human. This is how art can be seen as redeeming. Using this optimistic reading of Nietzsche, we can see humans as creators or artists who are encouraged to affirm life as they authentically shape their own lives to form a masterpiece.

One way in which we may shape ourselves in the manner of an artist shaping an artistic creation, is by reflecting on the impact of our gestures and how they assist or hinder the reception of our ideas in the world. We may then choose to refine our gestures: for instance, if one realises they appear gruff but wish to be well received, they may smile more. This is a simple example, but it illustrates the idea of creating 
ourselves as a pleasing (at least in one's own eyes) artwork. One may see the idea of living one's life as an artist recurring in Nietzsche's (1974) aphorism 'One thing is needful' in The Gay Science.

One thing is needful. - To 'give style' to one's character - a great and rare art! It is practiced by those who survey all the strengths and weaknesses of their nature and then fit them into an artistic plan until every one of them appears as art and reason and even weaknesses delight the eye. $(\$ 290)$

Note here that the artist is still using both logic (the Apollonian energy) alongside the creative Dionysian. This call to self-reflect is typical of the philosopher's urge to Know Thyself and here we see the self as an artwork that we can work on (become) as we try to cultivate moral virtues that are life-affirming. Swanton (2011, p. 137) calls Nietzsche an ethical egoist whose 'will to power' is framed in terms of life-affirming virtues. She argues,

The fundamental shape of an individual's life ought to be one in which that individual's life is affirmed or enhanced, and genuine enhancement occurs only if she expresses her "will to power" in a way that manifests or expresses virtue, or at least does not manifest or express vice. (p. 137)

The authentic life, then, is one which is life-affirming and includes virtuous habits that may be expressed through our gestures towards others.

\section{Schmid on Gestures and Developing an Art of Living}

As we have shown above, Nietzsche argues for life as an artful performance, one's life as being a work of art, and each person to be an artist of their own life. Nietzsche's holistic view of human beings as both rational and emotional, along with his concept of becoming the artist of one's own existence have influenced Schmid's (2000a; 2000b) concept of the art of living. Schmid argues that to develop one's own art of living one has to take responsibility for one's own life and try to make it a beautiful one. Schmid uses the term 'beautiful life' instead of 'good life' to emphasise the subjective nature of aesthetic taste. This is not to imply an abolishment of moral aspects of life, but to place emphasis on the uniqueness of each individual. Even while allowing individual and contextual variances in how a beautiful life may be lived, there still remains normative values such as care for the self and care for others that manifest as a part of a subjectively beautiful life. To shape one's own life means to become an artist and to make one's life a work of art. In this way, Schmid's notion of the art of living, like Nietzsche's, is an active one. A beautiful life is one that is pursued actively and, as 
agents who construct and create our own lives, we are accountable for the work we ultimately create.

Schmid emphasises the notion of responsibility for shaping one's own life and acknowledges it takes labour to care for oneself (Teschers, 2010). Schmid balances his focus on the individual perspective of living a beautiful life with his acknowledgement that human beings are social animals. People mostly live in communities and, in order to live a beautiful life, one must consider that one's social surroundings are important, alongside one's individual autonomy. To live a good and beautiful life, Schmid argues, it is not only necessary to honour the structures and rules of the society in which one is living, but it is also helpful to be a part of and support an environment in which people are also striving towards a good and beautiful life. Aristotle's (trans. 1996) notion of phronesis (prudence and practical wisdom) provides the foundation to develop an ethics that originates in the 'enlightened self-interest' of each individual, yet expands towards a care for others, society, and humanity on a global level (Schmid, 2000a; 2000b; Teschers, 2015). Therefore, if each individual engaged in the art of living cares for themselves and the people around them with the shared goal of becoming active artists who create their own existence, a social environment is created that supports flourishing and the development of each person's beautiful life.

Schmid's art of living contains key concepts that are central to becoming the artist of one's own life: Bildung (self-cultivation, self-formation, including the cultivation of knowledge and prudence); self-reflection; and practical wisdom (phronesis). To develop one's own art of living and to become the artist of one's own life means, Schmid (2000a) argues, to take responsibility for one's own life and shape it according to one's own, self-reflected values and norms (Teschers, 2010). For the embodied human being, as Nietzsche noted, these considerations have to reach beyond the rational and include the emotional sphere, especially in relation to interactions with other human beings. Gestures and bodily expressions of any kind, Schmid (2000b) argues, are the expression of the inner self and the art of living incorporates an art of gestures which culminates in an artful and purposeful performance of 'being' - a life-performance.

Gestures express on a conscious as well as sub-conscious level our emotions and, to some extent, our state of mind. If a person is sad, hurt or happy, it is via facial expressions, body posture, their gaze, voice, and many other gestures that convey the emotions being experienced by this person. We also express our thoughts in similar ways: for example, during a discussion a frown lets our companion know that we disagree or disprove, whereas agreement is often expressed by nodding and making affirming sounds. In addition, some gestures may be sub-conscious expressions of our inner self, and they may express our values and beliefs. For instance, the manner in which we approach another person can be friendly and supportive, it can be neutral, or it can be intimidating. This demonstrates that the way we use space, facial expressions and other gestures impacts on the people around us. Schmid (2000b) argues that for one's own art of living, one has to consciously reflect on one's habitual gestures to 
discern if one is acting according to one's values and beliefs or contrary to them. This reflection and the active and conscious labour of shaping and modelling one's gestures create an artful life-performance which allows an individual to act in an authentic manner according to their personal values and beliefs.

\section{Developing young people's life-performance using gestures}

One way in which the gestures and developing life-performance of young people may be explored and supported is in an educational context. As a form of communication, gestures are used in relation to others. Therefore, collaborative forms of pedagogical activity are well suited to their expression. Some examples of collaborative praxis may be found in drama education, and others in the approach to teaching philosophy to young people known as philosophy for children (P4C). We claim that both offer useful techniques that teachers may incorporate into their classroom in order to allow students to play with gestures within the context of an artful discovery of their own life-performance.

Philosophy for Children as a movement can be traced back to 1972 when Matthew Lipman, along with Ann Margaret Sharp, founded the Institute for the Advancement of Philosophy for Children (IAPC) at Montclair State College (now University) in the USA. Over the next 15 years, the IAPC produced a series of novels that explored philosophical ideas at an age-appropriate level for school-aged children along with accompanying teaching manuals. Subsequently, teachers and academics in many countries have written additional novels, short stories and teacher manuals which reflect a broad range of cultural traditions, while preserving core elements of Lipman's vision. With the aim of producing reasonable and democratic citizens, Lipman $(1988 ; 1991)$ decided that philosophical thinking skills were sorely needed in society. Influenced by the pragmatism of John Dewey and the developmental psychology of Lev Vygotsky, the central methodology for teaching philosophy was the community of inquiry (CoI). As Haynes (2014, pp. 1201-2, citing Lipman, 1988, 1991) explains:

The community of inquiry has a structure which evokes the spirit of cooperation, care, trust, safety, and a sense of common purpose and inquiry, which, in turn, evokes a form of self-correcting practice driven by the need to transform that which is intriguing, problematic, confused, ambiguous or fragmentary into some kind of unifying whole which is satisfying to those involved.

In a CoI, students usually sit in an inward-facing circle whereby the teacher acts as a facilitator of the dialogue. The philosophical discussion is responsive to the students' ideas and questions, allowing the participants in the inquiry to themselves be the authoritative philosophical voices rather than following a traditional pedagogical method of looking to the teacher for definite answers. A CoI may be prepared for by 
initially utilising an age appropriate provocation such as a text or object which invites students' questions, one of which is subsequently chosen as the focal question for the CoI. Traditionally, P4C practitioners use Lipman's own novels as the initial stimulus, which are imbued with philosophical concepts and ethical dilemmas. For example, if teachers wanted to use a CoI to reflect upon the aesthetic concepts that are present in artworks, they could choose the Lipman novel Suki (1978) which explores aesthetic concepts. This sets the framework for a CoI on the notion of aesthetic experience and/or exploring the concept and definition of art.

In a well-functioning $\mathrm{CoI}$ one would expect to see reasonable disagreement alongside virtuous responses to other participants including compassion and trust. Instead of being guided towards a teacher-set assumption, the CoI dialogue follows the line of inquiry where it leads (Lipman, 1991, p. 16). Ultimately the goal of the group of inquirers is to eliminate untruths, and eventually come to a shared 'best view of things to date' (Splitter, 2011, p. 497). Participants thus view themselves as one amongst a community of learners who build upon each other's ideas rather than simply arguing against each other in an attempt to prove they are 'right'. Intellectual humbleness is valued as a space is created for self-correction and reflection upon ideas shared in a safe classroom environment which will contain multiple, diverse voices (Lipman, 1991, p. 52). In this way the CoI encourages the development of critical thinking, caring responses and collaborative meaning-making.

$\mathrm{P} 4 \mathrm{C}$ and the concept of the art of living align well in their holistic approach to education and the CoI is well suited to explore concepts that are central to the development of an individual art of living (D'Olimpio \& Teschers, 2016). In both approaches, students are, for example, seen as lifelong learners who need to develop skills and knowledge that supports the development of a good and beautiful life. Some of the skills relevant for the development of one's own art of living are critical reflective thinking, the development of prudence and practical wisdom, as well as a range of curriculum topics, such as the human being as individual, the social human being, and difficulties and burdens of human life, to name only a few examples. It has been argued before that $\mathrm{P} 4 \mathrm{C}$ and the $\mathrm{CoI}$ pedagogy are well suited to support the development of these critical skills and to explore the curriculum areas that are particularly relevant for children to developing their own art of living. In addition to the contribution P4C can make to one's art of living, we argue here that drawing on drama education in combination with $\mathrm{P} 4 \mathrm{C}$ practice can open up an additional avenue for students to actively reflect on their life's pathway, the norms and values to which they ascribe, and assist the active shaping of one's own person, including their interaction with others, using gestures.

Using role play and drama to explore ideas and narratives is not new and many drama educators use this method. In terms of combining drama with $\mathrm{P} 4 \mathrm{C}$, there are fewer examples of this. This may possibly be due to the fact that a teacher who facilitates such dramatic inquiry will require pedagogical tools in both philosophy and 
drama. Furthermore it may be that $\mathrm{P} 4 \mathrm{C}$ techniques are brought into the drama classroom, or, alternatively, drama techniques could be used in a P4C class. ${ }^{1}$ Our suggestion is that teachers who are already making use of P4C pedagogy such as the CoI may wish to supplement this methodology with techniques gleaned from drama education in order to further enhance their classroom praxis.

How does combining P4C and drama help children develop their own art of living while respecting and supporting the development of the good and beautiful life of others? There are learning opportunities that drama education can provide, most notably in the areas of creativity, imagination and emotional development. These may support and supplement the critical thinking skills and caring responses encouraged in a CoI. Dramatic play invites actors to imagine situations and other people's identities, reflect on possible or likely personality traits of these characters, and imagine and reflect on how these traits should or are likely be expressed in relation to the scene that is to be enacted. Also, through enacting quality literature plays, engagement with 'the human' aspects of social interaction, including attending to the gestures of one's self and others, will play a significant role in the reflection and imagination process, which can support the social and emotional understanding and development of students, which in turn supports a reflected and caring engagement with 'the other' as is important for the development of an art of living.

Nussbaum has defended the way we can learn, morally, from narrative artworks, by practicing a caring disposition towards characters and the situations in which they find themselves. By practicing this moral attitude in relation to characters in stories, we are protected in a safe fictional space and therefore may find it easier to take the perspective of others. As Nietzsche told us, it is through art that we are united in the common experience of 'being human'. Nussbaum (2001) explains,

The aesthetic activity, which takes place in a safe and protected 'potential space' where our own safety is not immediately threatened, harnesses the pleasure of exploring to the neediness and insufficiency that is its object, thus making our limitations pleasing, and at least somewhat less threatening, to ourselves. (p. 244).

While we may teach ethics in a classroom, or read moral stories and invite children to act them out, we also need to find opportunities for young people to reflect upon and practice ethical behaviour. This can be done by using $\mathrm{P} 4 \mathrm{C}$ pedagogy in conjunction with drama techniques. After enacting a play or a scene from a text, for example, teachers can use a CoI to support the reflection on the gestures and art of living being

1 Three examples of using philosophical inquiry in conjunction with drama include Gordon Poad's 'dramatic enquiry' at cap-a-pie (www.cap-a-pie.co.uk/), The Philosophy Foundation (www.philosophy-foundation.org/), and Dorothy Heathcote's 'mantel of the expert' approach (www.mantleoftheexpert.com/). 
performed by students. The CoI dialogue may focus on the roles enacted, the social situations that are played out, and the effect that certain actions and reactions have on other characters in the play. Such discussion can further strengthen students' awareness of how actions and expressions impact upon others by provoking certain emotions in the person displaying these expressions and gestures, and in the people perceiving them.

By creating space in a classroom for children to consciously reflect on the relationship between personal values and how certain actions align or conflict with these, teachers can support the development of a child's own art of living. Drawing on Schmid's theory alongside Nietzsche's idea of living one's life as an artist, drama education and $\mathrm{P} 4 \mathrm{C}$ combined can offer teachers pedagogical tools to use in the classroom that invite students' conscious reflection on their actions and expressions their gestures - with a view to shaping their own set of habitual gestures towards a personal, deliberately developed, life-performance. Following Schmid's reasoning, a conscious engagement with and reflection on one's own set of gestures in relation to norms and values also encourages students to critically reflect on the norms and values they have adopted from society (e.g. parents, peers, religion, culture), and to make deliberate and reasoned decisions for or against certain norms and values. In this way students may take responsibility for their own beliefs and ultimately shape their lives accordingly.

If teachers create space in their $\mathrm{P} 4 \mathrm{C}$ classroom for drama techniques such as improvisation, mime and dramatic re-enactment, this can allow children to explore and experiment with gestures in a way that supports the development of their own lifeperformance. By acting out various diverse characters, students are given the opportunity to see which expressive actions best fit with their own individual character. Combining these techniques with $\mathrm{P} 4 \mathrm{C}$ methodology such as the CoI, participants are given the opportunity to attend to the gestures they and others employ, reflecting on their impact, which can lead to a conscious choice of the gestures and expressions they use. As Nietzsche spoke about giving 'style' to one's character, Schmid's notion of an art of living is also a matter of conscious choice.

\section{Playing with Philosophy in the Classroom: P4C and Drama Education}

It has been outlined above that, by encouraging the natural playfulness of children, P4C teachers may creatively engage students to think, reflect and be more aware of the impact their gestures have on others. Drawing from the dramatic arts, teachers may supplement a CoI, for instance, by stimulating student questions in an embodied manner prior to facilitating a purely verbal dialogue. This can be done by asking the students to firstly act out the stimulus text, possibly stopping the narrative at a crucial juncture and asking the students 'what do you think happens next?' and 'how do you feel / what do you think about that?' (Worley, 2010). After the students have acted out the story with various possible endings, teachers may use a pedagogical activity such as a Question 
Quadrant (Cam, 2006) before selecting a philosophical question upon which to base a CoI.

The Question Quadrant was designed by Cam to help students identify philosophical questions. After reading a story, for instance, students may brainstorm questions that emerge from engaging with the text and can then categorise them into one of four spaces on the quadrant designated as 'open' or 'closed' questions (horizontal axis), or 'textual' or 'intellectual' questions (vertical axis). A question is considered philosophical if it is open, 'deep', and does not yield an immediately obvious answer. A philosophical question invites contemplation, wonder, and will generate multiple answers, even though some answers will be more reasonable, justified and sound than others. It is philosophical questioning that is at the heart of a well-functioning CoI, along with trust and an empathetic engagement with others (D'Olimpio, 2015). An important aspect to good facilitation of a $\mathrm{CoI}$ is that the facilitator can recognise philosophical questions and concepts when they emerge, which highlights the importance of $\mathrm{P} 4 \mathrm{C}$ training and aspects of philosophical study in teacher education.

A holistic approach to education attends to verbal as well as non-verbal communication, and, thus, bringing drama techniques into the $\mathrm{P} 4 \mathrm{C}$ classroom caters to the active, physically expressive aspect of exploring ideas along with the quiet, thoughtful contemplation that is usually associated with the study of philosophy. A benefit of acting out stories from $\mathrm{P} 4 \mathrm{C}$ texts is that students may physically embody different perspectives while role-playing various characters before discussing the relevant concepts in a CoI. This works particularly well for students who may struggle with literacy competency, as well as for energetic, active personalities.

In a holiday workshop that combined drama, literacy and philosophy for children aged between K-5 (Kindergarten to year 5 or $3-9$ year olds), we saw the difference in the level of understanding made possible to young children when dramatic enactment accompanied a discussion of philosophical concepts found in age appropriate stories such as Aesop's Fables and classic fairy tales (D'Olimpio, 2004). In this workshop the students were read the classic story of Hans Christian Andersen's (1835) 'The Princess and the Pea' and then asked to act as if they were princesses. All the children, boys and girls, chose coloured material and moved around the room as they embodied their concept of royalty. They were then divided in to small groups and asked to devise a test or machine of some kind that would check to see if someone really was a princess or not. After they had come up with many imaginative ways of testing princess-like qualities, a discussion or CoI was held that investigated what qualities a princess would have, and why. This dialogue moved in the direction of defining the virtues themselves and exploring what constitutes good character. The level of discussion and understanding amongst the young participants was enhanced by their having had the opportunity to physically explore and play with the concept prior to joining with others in verbal dialogue. 
The imaginative play and dialogue that occurs as a result of dramatically engaging with a traditional story also makes room to challenge the conventional or stereotypical gendered (and other) associations that are made and often assumed in society. An example of this was evident in how the young children were re-writing the stories and acting out various endings. The classic 'sensitive princess is saved by a prince and lives happily ever after' trope was turned on its head in various ways as the characters and storylines were transformed by the children who explored various tests that might be conducted to judge if someone (of either gender) was 'good'. Hence, the children in this workshop engaged with the moral concept of 'good' as well as playfully transformed storylines which originally included concepts that were framed in gendered or stereotypical ways. A teacher in this context also has the opportunity to run a CoI on notions of gender and this may be done in an age-appropriate manner, depending on the age of the group with which one is working. This particular session was completed with a reading of a re-worked, feminist version of the classic story, 'The Princess on the Nut' by Michelle Nikly (1981).

Highlighting the creative thinking that works alongside the critical and caring thinking, drama techniques such as role-play, mime, performance and improvisation may supplement and support the philosophical discussion of ideas. This would particularly benefit younger children who are physically expressive and attracted to creative expression and playful exploration of their thoughts and feelings (Toye, 1994). As students participate in dramatic inquiry (a term coined by Gordon Poad from cap-apie in the UK; see http://www.cap-a-pie.co.uk/about/gordon-poad/ for more information), they learn by doing, that is to say, they learn by interacting with others. In this way, they see the differences between themselves, their peers, and the various characters that are being enacted, but they also get the sense of a shared humanity.

Practising habits that involve treating others with respect is the idea behind Lipman's (1991) goal of producing democratic citizens who engage with and care about the world, the environment and the people in it, which links with Schmid's (2000a) ethical considerations in which each individual, through prudence and practical wisdom, comes to understand that to care for oneself consequently means to also care for others, humanity and the world we are living in. Lipman's central methodology of the CoI encourages the participants to care about one another as members of a group who are making meaning together.

Combining the CoI with playful yet reflective engagement with relevant world literature in the form of drama and plays can only serve to augment the pedagogical benefits of teaching philosophy to young students. P4C is already imbued with the concept that rich narratives should be used as stimulus texts in order to encourage students' curiosity and to provoke philosophical inquiry (Sprod, 2001, p. 160 discusses this point and refers to Lipman's novels and Lipman \& Sharp's accompanying teacher manuals). Narrative artworks may assist us to engage imaginatively and empathetically with characters in a safe, protected fictional space, and we can then practice this 'loving 
attitude' in relation to real world scenarios (Nussbaum, 1987, 1998b). If literature can assist us to practice such a moral attitude, then artworks may have the ability to assist us to develop habits that are conducive to flourishing (Sprod, 2001, pp. 197-8; Nussbaum, 1995, p. 75), as well as being aesthetic ingredients of a good life. If encountering a range of characters and human interactions through drama and literature can sharpen one's awareness of their own gestures and habits, then one is able to reflect upon the impact one has on other human beings through gestures and expressions. Becoming aware of one's gestures and reflecting upon them to develop an artful, conscious performance of interaction with others that is based on respect and a care for the other is part of the development of one's own art of living and an education for life.

\section{Conclusion}

In this article, we have explored how playing with philosophy in the classroom using pedagogical tools such as the CoI alongside drama education can help students to purposefully develop a set of reflected gestures, an artful performance of life. By considering Nietzsche's idea of living life as an artist, along with Schmid's concept of gestures within his pedagogy for the art of living, we can see how Philosophy for Children (P4C) practitioners may engage with concepts of art and drama to support children to develop their own art of living while respecting and supporting the development of the good and beautiful life of others. This holistic approach to education emphasises the importance of training children to be both reasonable and compassionate, and to practice critical, caring and creative thinking skills precisely because humans are embodied and social beings. The telos of education, according to Lipman $(1988,1991)$, is to encourage students to think for themselves, and ultimately live collaboratively as democratic citizens who judge ideas they are presented with and who have the freedom to creatively explore and develop their own talents and interests. Two philosophical frameworks that we have drawn upon that align with this pragmatic and inclusive view of gaining knowledge or practical wisdom are Nietzsche's idea of living one's life as an artist and Schmid's philosophy of the art of living. Teachers may use dramatic inquiry in their classrooms in order to create a safe space for students to reflect on their beliefs, norms and values and how their actions and habitual gestures relate to these. In this way, drawing upon drama and $\mathrm{P} 4 \mathrm{C}$ techniques, educators can support the development of their students' own art of living, help them to shape themselves and to take steps towards becoming the artists of their own beautiful life. Educational institutions need to aim higher than towards measurable standards in reading, writing and maths and we argue that philosophy and the arts have an important role to play for the development of our children's character and way of being. As a society, we should aim towards creating an environment that allows all human beings to live beautiful lives and to become the artists of their own meaningful life. 


\section{References}

Andersen, H. C. (1835). The Princess and the Pea. Trans. Charles Boner. Copenhagen, Denmark: C. A. Reitzel.

Aristotle. (trans. 1996). The Nicomachean Ethics. London, England: Wordsworth Editions Limited.

Cam, P. (2006). Twenty thinking tools. Camberwell, Australia: ACER. A modified version of the Question Quadrant retrieved from http://www.philosophyineducation.com/resources/Question+Quadrant.pdf

D’Olimpio, L. \& Teschers, C. (2016) Philosophy for Children meets the Art of Living: a holistic approach to an Education for Life. Philosophical Inquiry in Education, 23(2), 114-124 retrieved from: http://journals.sfu.ca/pie/index.php/pie/article/view/422

D’Olimpio, L. (2015) "Trust, Well-being and the Community of Philosophical Inquiry" He $\quad$ Кири 4(2), 45-57. Retrieved from http://www.hekupu.ac.nz/Journal\%20files/Issue2\%20October\%202015/Lau raDOlimpio.pdf

D’Olimpio, L. (2004) Drama and Philosophy: Language, thinking and laughing out loud! International Drama Educators Association (IDEA) Vol 5 / Applied Theatre Research Journal, 3, retrieved from: http://www.griffith.edu.au/_data/assets/_pdf_file/0007/54952/dramaphilosophy.pdf

Haynes, F. (2014). Editorial. Educational Philosophy and Theory, 46, 1197-1202.

Kerruish, E. (2009). Interpreting feeling: Nietzsche on the emotions and the self. Minerva - An Internet Journal of Philosophy, 13, 1-27.

Lipman, M. (1978) Suki. Upper Montclair, NJ: Institute for the Advancement of Philosophy for Children (Montclair State College).

Lipman, M. (1988). Philosophy goes to school. Philadelphia, PA: Temple University Press.

Lipman, M. (1991). Thinking in Education Cambridge, England: Cambridge University Press.

Nietzsche, F. (1872). The Birth of Tragedy, trans. Clifton P Fadiman, New York, NY: Dover.

Nietzsche, F. (1974). The Gay Science, translated by Walter Kaufmann. New York, NY: Vintage Books.

Nikly, M. (1981). The Princess on the Nut: or the curious courtship of the son of the princess on the pea. Trans. by Lucy Meredith. Pictures by Jean Claverie. London: Faber and Faber. 
Nussbaum, Martha (2001). Upheavals of Thought: the intelligence of emotions, Cambridge, England: Cambridge University Press.

Nussbaum, M. (1998a). The Transfigurations of Intoxication: Nietzsche, Schopenhauer and Dionysus. In G. Kemal \& Conway (Eds.), Nietzsche, Philosophy and the Arts (pp. 36-69). Cambridge, England: Cambridge University Press.

Nussbaum, M. (1998b). Exactly and Responsibly: A Defence of Ethical Criticism. Philosophy and Literature, 22(2), 343-365.

Nussbaum, M. (1995). Poetic Justice. Boston, MA: Beacon Press.

Nussbaum, M. (1987). Finely Aware and Richly Responsible: Literature and the Moral Imagination. In Literature and the Questions of Philosophy by Cascardi, J (Ed). Baltimore: John Hopkins University Press.

Schmid, W. (2000a). Philosophie der Lebenskunst. Eine Grundlegung. Frankfurt, Germany: Suhrkamp.

Schmid, W. (2000b). Auf der Suche nach einer neuen Lebenskunst. Frankfurt, Germany: Suhrkamp.

Swanton, C. (2011). Virtuous Egoism and Virtuous Altruism. In Gotthelf, A. \& Lennox, J. (Eds). Metaethics, Egoism, and Virtue (pp. 131-142). Pittsburgh, PA: University of Pittsburgh Press.

Splitter, L. (2011). Identity, citizenship and moral education. Educational Philosophy and Theory, 43(5), 484-505.

Sprod, T. (2001). Philosophical Discussion in Moral Education: the community of ethical inquiry. London, England: Routledge.

Teschers, C. (2010). 'Lebenskunst' - Schmid's Concept of the Art of Living. In PESA Conference Proceedings 2010. Perth, Australia: Philosophy of Education Society of Australasia. Available from: http://pesa.org.au/images/papers/2010-papers/pesa-2010-paper-02.pdf.

Teschers, C. (2015). The Role of Friendship and Partnership in an Education for Life. Knowledge Cultures, 3(5), 92-101.

Toye, N. (1994) On the Relationship Between Philosophy for Children and Educational Drama. Thinking, 12(1), 24-26.

Worley, P. (2010). The If Machine: Philosophical enquiry in the classroom. London, England: Bloomsbury. 